\title{
PREDICTING FACTORS CONTRIBUTING TO LENGTH OF STAY IN HOSPITALIZED CHRONIC OBSTRUCTIVE PULMONARY DISEASE (COPD) PATIENTS: THE ROLE OF THE EMERGENCY ROOM
}

\author{
José Antonio Díaz-Peromingo' ${ }^{1}$, Jesús Grandes-Ibánez ${ }^{1}$, José Manuel Fandino-Orgeira², Pablo Barcala-Villamarín², \\ Juan Antonio Garrido-Sanjuán
}

Hospital Arquitecto Marcide, El Ferrol, Spain: Department of Internal Medicine ${ }^{1}$; Hospital Da Barbanza, Riveira, Spain: Emergency Department ${ }^{2}$

Summary: Background: Exacerbation of chronic obstructive pulmonary disease (COPD) is a common cause of hospital admission and COPD patients usually have a long stay in hospital. Methods: The objective of this study was to identify factors predicting length of stay in patients with exacerbation of COPD when seen in the emergency room. We analyzed clinical and biological variables. Results: Patients with diminished breath sounds, systolic pressure higher than $140 \mathrm{mmHg}$, diastolic pressure higher than $90 \mathrm{mmHg}$ and recent previous hospitalization for exacerbation of COPD had the longest hospital stay. Conclusions: Recognition of this clinical profile in the emergency room may help to increase efforts in order to diminish length of stay in these patients.

Key words: Chronic obstructive pulmonary disease; Length of stay; Hospitalization

\section{Introduction and objective}

Economic aspects are of increasing importance in health care. In addition, some conditions like chronic obstructive pulmonary disease (COPD) are common causes of hospitalization in developed countries. COPD refers to a wide spectrum of chronic respiratory diseases characterized by dyspnea, cough, airflow limitation, sputum production and impaired gas exchange (5). Acute exacerbations of COPD are commonly managed at hospital. Inpatient treatment is associated with high cost mainly because the average length of hospitalization in COPD patients is high. Although many issues remain unresolved, the relationship between the cost of medical treatment and the length of hospitalization has been investigated. It has been reported that treatment costs correlated with the duration of hospital stay (14), but this relationship needs further investigation. Noninvasive ventilation can reduce the length of stay in selected patients, the need for endotracheal intubation, and in-hospital mortality rate (2). On the other hand, oral corticosteroid treatment was found to be associated with a longer hospital stay during end stage COPD in women (15). Antibiotics, especially sequential therapy may also lead to substantial savings in terms of length of hospital stay and associated medical costs (16). Other studies have found a mean number of hospitalization days increased among women (7). Alternatives to hospitalization, such as emergency diagnostic and treatment units, have been evaluated in terms of length of stay, patient satisfaction and quality of life, with favorable results in asthma patients (10). Aspects such as readmission after hospital discharge have also been investigated. Thus, Camberg et al. found that patients discharged to nursing homes were less likely to be readmitted within 30 days, than patients discharged home (4). A lower quality of inpatient care increases the risk for unplanned early readmission in COPD patients (1). Besides, patients who have had several hospitalizations for COPD exacerbation in the previous year tend to be readmitted and have a longer stay in hospital (3). On the other hand, outpatient rehabilitation programs have shown significant reductions in the number of days of hospitalization in the four years following entry into the program when compared to the year prior to rehabilitating therapy (6).

Most hospital admissions in CODP patients are decided at the emergency room. We wondered if we could predict the global length of hospital stay on clinical and analytical grounds. Thus, the aim of this report is to identify factors that predict length of hospital stay, especially prolonged hospitalization, in patients with COPD at the emergency room. We analyzed the relationship between clinical and biological variables and the days of hospitalization for exacerbation of COPD. Then, we attempted to identify a clinical profile of prolonged stay in order that measures could be developed to reduce hospitalization in such patients. 


\section{Methods}

We studied retrospectively 68 consecutive patients admitted to our general hospital with exacerbation of CODP defined as increasing in symptoms (cough, dyspnea and/or sputum production), with or without fever, worsening of respiratory failure (at least $10 \mathrm{mmHg}$ diminution in $\mathrm{PaO} 2$ as compared with patient's baseline $\mathrm{PaO} 2$ ) and/or chest radiographic abnormalities. All of them had been hospitalizated previously for COPD at least once in the previous 2 years. Diagnosis of COPD had been made at least 3 years before, on clinical and spirometric grounds. Duration of acute symptoms ranged between 1 and 10 days before emergency room admission. Patients were managed by Internists recording age, sex, other concomitant diseases, respiratory symptoms, findings on physical examination, laboratory variables, electrocardiographic findings, chest radiographic films, previous antibiotic treatment (within 2 weeks), recent hospitalization for exacerbating COPD (within 3 months), supplemental oxygen use at home, quality of life (Karnofsky scale)(13) and length of stay. Data was complete in every patient. We grouped some variables in order to identify specific correlation between these variables and the duration of stay, and to identify interaction between variables. We chose some variables because they clearly could influence length of stay (eg, age, arterial blood $\mathrm{PCO}_{2}$, hemoglobin). Other variables showed no apparent relationship with length of stay (eg, sodium plasma concentration, hemoptysis, respiratory rate) but we wished to establish whether they had any effect. $\mathrm{FEV}_{1}$ measure was recorded in only 12 patients at the emergency room, so this variable was not included in the study. Patients were discharged after clinical, laboratory findings (especially arterial blood PO2) and radiographic improvement. Statistical analysis was made using one-way ANOVA, and logistic regression between length of stay as dependent variable and all the other ones.

\section{Results}

In the 68 CODP patients, 29 (42.6\%) were women and $39(57.4 \%)$ men. Median age was 73 (range 48-93) years. Average length of stay was 16 (range 5-92) days. This median score was used as breakpoint for dichotomizing the group. So, we divided the length of stay into two groups; 16 days or less (41 patients) and greater than 16 days (27 patients). Four patients (5.9\%) died during hospitalization. Table 1 shows non-analytical data. After one-way ANOVA analysis, breath sound diminution $(\mathrm{p}=0.0202)$ and previous hospitalization $(\mathrm{p}=0.0141)$ reached statistical significance ( $p<0.05,95 \%$ confidence interval). Tables 2 and 3 show analytical data. On logistic regression we used as dependent variable length of stay divided in two groups, 16 days or less and greater than 16 days. Among non dependent variables, high diastolic blood pressure $(p=0.0416)$, and high systolic blood pressure $(p=0.0239)$ were statistically significant ( $<<0.05,95 \%$ confidence interval).
Tab. 1:

\begin{tabular}{|c|c|}
\hline Variable & One-way ANOVA \\
\hline Sex. & $0.8113(\mathrm{NS})$ \\
\hline $\begin{array}{l}\text { Previous diseases: } \\
\text { - Ischaemic heart disease. } \\
\text { - Liver cirrhosis. } \\
\text { - Diabetes mellitus. } \\
\text { - Hypercholesterolemia. } \\
\text { - Hypertension. } \\
\text { - Heart failure. }\end{array}$ & $\begin{array}{l}0.3268 \text { (NS) } \\
0.2505(\mathrm{NS}) \\
0.6733(\mathrm{NS}) \\
0.2189(\mathrm{NS}) \\
0.5802(\mathrm{NS}) \\
0.6037(\mathrm{NS})\end{array}$ \\
\hline $\begin{array}{l}\text { Respiratory symptoms: } \\
\text { - Dyspnea. } \\
\text { - Pleuritic chest pain. } \\
\text { - Sputum production. } \\
\text { - Hemoptysis. } \\
\text { - Confusion. }\end{array}$ & $\begin{array}{l}0.4212(\mathrm{NS}) \\
0.5396(\mathrm{NS}) \\
0.2156(\mathrm{NS}) \\
0.8208 \text { (NS) } \\
0.3039 \text { (NS) }\end{array}$ \\
\hline $\begin{array}{l}\text { Physical examination: } \\
\text { - Crackles. } \\
\text { - Central cyanosis. } \\
\text { - Pretibial edema. } \\
\text { - Hepatomegaly. } \\
\text { - Breath sound diminution. } \\
\text { - Wheezes. } \\
\text { - Cough }\end{array}$ & $\begin{array}{l}0.6553(\mathrm{NS}) \\
0.7594(\mathrm{NS}) \\
0.0791(\mathrm{NS}) \\
0.5425(\mathrm{NS}) \\
0.0202(*) \\
0.5101(\mathrm{NS}) \\
0.5396(\mathrm{NS})\end{array}$ \\
\hline $\begin{array}{l}\text { Electrocardiographic findings: } \\
\text { - Right bundle branch block. } \\
\text { - Atrial fibrillation. }\end{array}$ & $\begin{array}{l}0.4295(\mathrm{NS}) \\
0.3497(\mathrm{NS})\end{array}$ \\
\hline $\begin{array}{l}\text { Chest radiographic abnormalities: } \\
\text { - Bronchiectasis. } \\
\text { - Cardiomegaly. } \\
\text { - Pneumonia. }\end{array}$ & $\begin{array}{l}0.3654(\mathrm{NS}) \\
0.8806(\mathrm{NS}) \\
0.6759(\mathrm{NS})\end{array}$ \\
\hline $\begin{array}{l}\text { Previous antibiotic treatment } \\
\text { ( } 2 \text { weeks prior to admission). }\end{array}$ & $0.3730(\mathrm{NS})$ \\
\hline $\begin{array}{l}\text { Recent hospitalization } \\
\text { ( } 3 \text { months prior to admission). }\end{array}$ & $0.0141(*)$ \\
\hline Supplemental oxygen at home. & $0.7906(\mathrm{NS})$ \\
\hline
\end{tabular}

(*) $\mathrm{P}<0.05$; Breath sound diminution: 0.0064-0.0482, $95 \%$ confidence interval.

Recent hospitalization: $0.0075-0.0442,95 \%$ confidence interval.

Numbers express $P$ values.

NS: non significant value.

One-way ANOVA for length of stay greater than 16 days.

\section{Discussion}

Mathur et al. identified only the admission heart rate as significant in calculating the odds of a patient staying longer than 5 days (9). In another study performed among patients admitted to an intensive care unit (ICU) with acute exacerbations of COPD, ventilation time and tracheostomy predicted the length of ICU stay and global hospital stay, respectively (11). Loukides el al. found that patients with insulin-dependent diabetes mellitus and associated COPD, 
Tab. 2:

\begin{tabular}{|c|c|c|}
\hline Variable & Patients & Logistic regression \\
\hline $\begin{array}{l}\text { Age: } \\
\text { - } \leq 59 \text { y/old. } \\
-60-69 \mathrm{y} / \mathrm{old} . \\
-70-79 \mathrm{y} / \mathrm{old} \\
-80-89 \mathrm{y} / \mathrm{old} \\
-90-100 \mathrm{y} / \mathrm{old}\end{array}$ & $\begin{array}{c}6 \\
20 \\
27 \\
11 \\
4 \\
\end{array}$ & $\begin{array}{l}0.3661(\mathrm{NS}) \\
0.3859(\mathrm{NS}) \\
0.1639(\mathrm{NS}) \\
0.0593(\mathrm{NS}) \\
0.4462(\mathrm{NS})\end{array}$ \\
\hline $\begin{array}{l}\text { Fever (body temperature } \\
\text { greater than } 38^{\circ} \mathrm{C} \text { ): }\end{array}$ & 68 & 0.3743 \\
\hline $\begin{array}{l}\text { Respiratory rate greater } \\
\text { than } 20 \text { / minute: }\end{array}$ & 68 & $0.5037(\mathrm{NS})$ \\
\hline $\begin{array}{l}\text { Quality of life (Karnofsky } \\
\text { scale less than } 60 \text { ): }\end{array}$ & 68 & 0.9836 \\
\hline $\begin{array}{l}\text { Systolic pressure: } \\
-\leq 100 \mathrm{~mm} \mathrm{Hg} \\
-101-140 \mathrm{~mm} \mathrm{Hg} \text {. } \\
->140 \mathrm{~mm} \mathrm{Hg} \text {. }\end{array}$ & $\begin{array}{c}1 \\
19 \\
48 \\
\end{array}$ & $\begin{array}{l}0.3743(\mathrm{NS}) \\
0.2896(\mathrm{NS}) \\
0.0239(*) \\
\end{array}$ \\
\hline $\begin{array}{l}\text { Diastolic pressure: } \\
-\leq 60 \mathrm{~mm} \mathrm{Hg} \text {. } \\
-61-90 \mathrm{~mm} \mathrm{Hg} \\
->90 \mathrm{~mm} \mathrm{Hg} \text {. }\end{array}$ & $\begin{array}{c}4 \\
53 \\
11 \\
\end{array}$ & $\begin{array}{l}0.4283(\mathrm{NS}) \\
0.3897(\mathrm{NS}) \\
0.0416\left({ }^{*}\right) \\
\end{array}$ \\
\hline $\begin{array}{l}\text { Heart rate: } \\
-\leq 100 \text { beats } / \mathrm{min} \\
->100 \text { beats } / \mathrm{min}\end{array}$ & $\begin{array}{l}51 \\
17 \\
\end{array}$ & $\begin{array}{l}0.9275(\mathrm{NS}) \\
0.6682(\mathrm{NS})\end{array}$ \\
\hline
\end{tabular}

(*) $\mathrm{P}<0.05,95 \%$ confidence interval. Numbers express $P$ values.

NS: non significant value.

Logistic regression: dependent variable length of stay.

with respiratory infections, have longer periods of hospitalization (8). In the study of Mushlin et al. three clinical variables on admission (high $\mathrm{PCO}_{2}$, symptoms present for more than 1 day and antibiotic treatment at admission) were associated with the need for longer hospitalization (12). After analyzing our results we found that, in our study and in this population, a patient with COPD exacerbation presenting in the emergency room is likely to have a length of stay greater than 16 days if the following profile is present: breath sound diminution on physical examination, systolic blood pressure higher than $140 \mathrm{~mm} \mathrm{Hg}$, diastolic blood pressure higher than $90 \mathrm{~mm} \mathrm{Hg}$ and hospitalization for the same condition within the previous 3 months. COPD involves some degree of interaction between variables. The possible benefit of recognizing this clinical profile is to focus on treatment actions in selected patients, to shorten hospital stay, and thus lead to considerable savings in medical costs and utilization of hospital resources. However, this study has some limitations. This is a retrospective study and some important variables such as $\mathrm{FEV}_{1}$ was not measured in all cases. Because of the small number of cases in some variables, we could not reach a minimum number of subjects in these variables affecting logistic regression. Some clinical tests such as DLCO are not readily
Tab. 3:

\begin{tabular}{|c|c|c|}
\hline Albumin less than $3 \mathrm{mg} / \mathrm{dL}$ : & 68 & $0.7940(\mathrm{NS})$ \\
\hline Creatinine greater than $1.2 \mathrm{mg} / \mathrm{dL}$ : & 68 & $0.7057(\mathrm{NS})$ \\
\hline Urea nitrogen greater than $50 \mathrm{mg} / \mathrm{dL}$ : & 68 & $0.4579(\mathrm{NS})$ \\
\hline $\begin{array}{l}\text { White-cell count: } \\
-<4.010^{9} / \mathrm{L} \\
-4.0-10.010^{9} / \mathrm{L} \\
->10.010^{9} / \mathrm{L}\end{array}$ & $\begin{array}{c}2 \\
42 \\
24\end{array}$ & $\begin{array}{l}0.5375(\mathrm{NS}) \\
0.8376(\mathrm{NS}) \\
0.9009(\mathrm{NS})\end{array}$ \\
\hline $\begin{array}{l}\text { Hemoglobin concentration: } \\
-<12 \mathrm{~g} / \mathrm{L} . \\
-12-18 \mathrm{~g} / \mathrm{L} \\
->18 \mathrm{~g} / \mathrm{L}\end{array}$ & $\begin{array}{l}16 \\
25 \\
27\end{array}$ & $\begin{array}{l}0.5367(\mathrm{NS}) \\
0.7835(\mathrm{NS}) \\
0.4348(\mathrm{NS})\end{array}$ \\
\hline $\begin{array}{l}\text { Sodium: } \\
\text { - <135 mmol/L. } \\
\text { - } 135-145 \mathrm{mmol} / \mathrm{L} . \\
\text { - >145 } \mathrm{mmol} / \mathrm{L} .\end{array}$ & $\begin{array}{c}3 \\
64 \\
1\end{array}$ & $\begin{array}{l}0.3463(\mathrm{NS}) \\
0.9786(\mathrm{NS}) \\
0.7875(\mathrm{NS})\end{array}$ \\
\hline $\begin{array}{l}\text { Potassium. } \\
-<3.5 \mathrm{mmol} / \mathrm{L} \\
-3.5-5.0 \mathrm{mmol} / \mathrm{L} \\
->5.0 \mathrm{mmol} / \mathrm{L}\end{array}$ & $\begin{array}{c}3 \\
61 \\
4\end{array}$ & $\begin{array}{l}0.5362(\mathrm{NS}) \\
0.4359(\mathrm{NS}) \\
0.2945(\mathrm{NS})\end{array}$ \\
\hline $\begin{array}{l}\text { Arterial blood } \mathrm{PO}_{2}: \\
-\leq 60 \mathrm{mmHg} \\
->60 \mathrm{mmHg}\end{array}$ & $\begin{array}{l}38 \\
30\end{array}$ & $\begin{array}{l}0.3536(\mathrm{NS}) \\
0.5154(\mathrm{NS})\end{array}$ \\
\hline $\begin{array}{l}\text { Arterial blood } \mathrm{PCO}_{2} \text { : } \\
-35 \mathrm{mmHg} \text {. } \\
-35-45 \mathrm{mmHg} \\
->45 \mathrm{mmHg} \text {. }\end{array}$ & $\begin{array}{l}10 \\
30 \\
28\end{array}$ & $\begin{array}{l}0.6387(\mathrm{NS}) \\
0.3845(\mathrm{NS}) \\
0.7625(\mathrm{NS})\end{array}$ \\
\hline $\begin{array}{l}\text { Arterial blood } \mathrm{pH}: \\
-<7.35 \\
-7.35-7.45 \\
->7.45\end{array}$ & $\begin{array}{l}17 \\
33 \\
18\end{array}$ & $\begin{array}{l}0.4762 \text { (NS) } \\
0.6735 \text { (NS) } \\
0.5803 \text { (NS) }\end{array}$ \\
\hline
\end{tabular}

(*) $\mathrm{P}<0.05,95 \%$ confidence interval. Numbers express $P$ values.

NS: non significat value.

Logistic regression: dependent variable length of stay.

available in most hospitals. On the other hand, most of the variables analyzed are currently available in most hospitals, and we believe that our results are applicable to other general or community hospitals, and especially to emergency rooms. How could we associate hypertension with worse evolution in COPD leading to high length of stay is unclear. Further studies, especially prospective studies, are needed to evaluate the relationship among hypertension, COPD and the clinical response to common treatments of exacerbating COPD.

\section{References}

1. Ashton C, Kuykendall D, Johnson M, Wray N, Wu L. The association between the quality of inpatient care and early readmission. Ann Intern Med 1995; 122(6):415-21.

2. Brochard L, Mancebo J, Wysocki M et al. Noninvasive ventilation for acute exacerbations of chronic obstructive pulmonary disease. N Engl J Med 1995; 333(13):817-22.

3. Burns R, Nichols L. Factors predicting readmission of older general medicine patients. J Gen Intern Med 1991;6(5):389-93 
4. Camberg L, Smith N, Beaudet M, Daley J, Cagan M, Thibault G. Discharge destination and repeat hospitalizations. Med Care 1997:35(8):756-67.

5. Ferguson G, Cherniack R. Management of chronic obstructive pulmonary disease. N Engl J Med 1993;328(14):1017-22.

6. Hudson L, Tyler M, Petty T. Hospitalization needs during an outpatient rehabilitation program for severe chronic airway obstruction. Chest 1976;70(5):606-10.

7. Keistinen T, Vilkman S, Tuuponen T, Kivela S. Hospital admissions for chronic obstructive pulmonary disease in the population aged 55 years or over in Finland during 1972-1992. Public Health 1996;110(4):257-9.

8. Loukides S, Polyzogopoulos D. The effect of diabetes mellitus on the outcome of patients with chronic obstructive pulmonary disease exacerbated due to respiratory infections. Respiration 1996;63(3):170-3.

9. Mathur R, Clark R, Dhillon D, Winter J, Lipworth B. Reaudit of acute asthma admissions using a severity marker stamp and determinants of an outcome measure. Scott Med J 1997;42(2):49-52.

10. McDermontt M, Murphy D, Zalenski R et al. A comparison between emergency diagnostic and treatment unit and inpatient care in the management of acute asthma. Arch Intern Med 1997;157(18):2055-62.

11. Morán J, Green J, Homan S, Leeson R, Leppard P. Acute exacerbations of chronic obstructive pulmonary disease and mechanical ventilation: a reevaluation. Crit Care Med 1998:26(1):71-8.

12. Mushlin A, Black E, Connolly C, Buonaccorso K, Eberly S. The necessary length of hospital stay for chronic pulmonary disease. JAMA 1991;266(1):80-3.
13. Osoba D, MacDonald N. Principles governing the use of cancer chemotherapy in palliative care. In: Doyle D, Hanks G, MacDonald N, eds. Oxford Textbook of Palliative Medicine. $2^{\text {nd }}$ edition. New York: Oxford University Press, 1998:255.2.

14. Riecke K, Eller J, Gericke C, Lode H. Inpatient treatment costs of exacerbated chronic obstructive lung disease. Pneumologie 1999;53(4):199-206.

15. Strom K. Oral corticosteroid treatment during long-term oxygen therapy in chronic obstructive pulmonary disease: a risk factor for hospitalization and mortality in women. Respir Med 1998;92(1):50-6.

16. Vogel F. Sequential therapy in the hospital management of lower respiratory in fections. Am J Med 1995;99(6B):14S-19S.

Submitted October 2003.

Accepted November 2003.

José Antonio Díaz-Peromingo, M.D., C/ Berna, $1 \mathrm{~A}$, 3s $\mathrm{B}$, 15703 Santiago de Compostela,

Spain. e-mail: jadiazperomingo@mundo-r.com 